\title{
Experimental research on the haulage drifts stability in steeply dipping seams
}

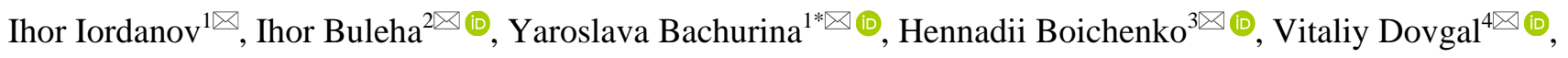

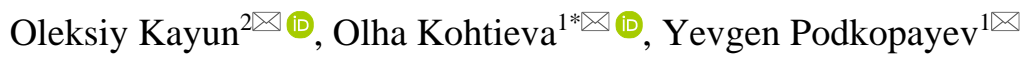 \\ ${ }^{1}$ Donetsk National Technical University, Pokrovsk, 85300, Ukraine \\ ${ }^{2}$ LLC "MC Elteko", Kostiantynivka, 85103, Ukraine \\ ${ }^{3}$ LLC "Sviato-Pokrovska \#3 Mine”, Pokrovsk, 85300, Ukraine \\ ${ }^{4}$ State Property Fund of Ukraine, Kyiv, 01133, Ukraine \\ *Corresponding author: e-mail olha.kohtieva@donntu.edu.ua, tel. +380952220252
}

\begin{abstract}
Purpose. Substantiation of the conditions for haulage drifts stability using different protection methods in steeply dipping seams based on a set of experimental studies.

Methods. To achieve the purpose set, mine instrumental observations have been performed to study the rock pressure manifestations in zonal advance workings adjacent to the stope face on the haulage horizon. The conditions for their maintenance, within the mining site, are assessed by the side rocks convergence value on the drift contour and the change in the cross-sectional area, taking into account the deformation properties of the protective structures.

Findings. It is recorded that in the zone of the stope works influence, in the most difficult conditions, haulage drifts are maintained, when coal pillars or clumps of prop stays are used for their protection. It has been determined that a decrease in the section of such mine workings up to $50 \%$ is the result of the protective structures destruction. When protecting the hau-lage drifts with the rolling-on chocks, a decrease in the mine working section up to $30 \%$ occurs in the process of the protective structures compression. It has been revealed that deformation of coal pillars or clumps of prop stays up to 10 $20 \%$ leads to a loss of their stability, and an increase to $60 \%$ leads to a complete loss of their load-bearing capacity, intensification of rock displacements on the mine working contour and deterioration of its stability. It has been determined that in the process of deformation of the rolling-on chocks from sleepers by 20-60\%, they are compressed without loss of load-bearing capacity, which ensures a smooth deflection of the overhanging stratum and restriction of rock displacements on the haulage drift contour.
\end{abstract}

Originality. To study the deformation characteristics of protective structures above the drift, the function of the increment is used of side rock displacements on the haulage drift contour along the mining site length dependent on the relative deformations of protective structures, which makes it possible to assess the real dynamics of the process.

Practical implications. When mining steep coal seams, using the specificity of geomechanical processes, which are manifested in an anisotropic coal-rock mass during unloading, satisfactory mine workings stability can be ensured by changing the deformation properties of protective structures above the drift.

Keywords: rock pressure, drift, maintenance of mine workings, pillar, chocks, protective structures, rocks, coal-rock mass

\section{Introduction}

The problem of ensuring the stability of advance workings at the mining sites of deep coal mines is one of the main ones in improving the technical-and-economic performance of the enterprise [1], [2]. Advance workings ensure the preparation of the mine field areas and minerals mining at the mining sites. For the regular mining sites operation, it is necessary that the section of the zonal advance workings adjacent to the stope face satisfies the requirements of the Safety Rules (SR) [3].

Analysis of the mine workings state in the mines developing the steeply dipping coal seams indicates that about $50 \%$ of the haulage drifts length have sections that do not meet the performance requirements [4]. The unsatisfactory mine workings state and the repair work implementation in them negatively affects the stope face operation, worsening 
the conditions for mining site ventilation and reducing the safety level when conducting mining operations [5].

The protection of zonal advance workings is a set of mining and technological measures designed to ensure their operating state in accordance with the requirements of regulatory documents [3]. The search for reliable methods of protecting the haulage drifts is one of the main directions for increasing the efficiency of steep coal seams mining, which means that it confirms the relevance of these studies to ensure the stability of zonal advance workings in deep coal mines [1]. The safety of work, the timely reserves development at the mining sites and the technical-and-economic performance of the coal enterprise depend on the appropriate solution to this problem.

\subsection{Analysis of literary sources}

The global experience of deep mines operation indicates that the efficiency of mining the coal seams at great depths depends on the side rocks stability in the stope face and the state of the exploited mine workings [2]. The side rocks stability in the coal-rock mass containing the mine workings is largely determined by the method for controlling the roof in the stope face. The state of haulage drifts at mining sites depends on the method used to protect the advance workings [6], [7].

Currently, at the most coal mines mining the steeply dipping coal seams, the method of supporting the roof on chocks or complete caving of the roof is used to control the rock pressure in the stope face. It is noted in the works [7], [8] that when the roof is supported on chocks, the side rocks stability and the operating state of the zonal advance workings are ensured. At the same time, when using this method, stable and safe operation of stope faces is not always guaranteed. This is caused, first of all, by the formation of uncaved roof areas behind the stope face. The negative consequences of such a geomechanical situation can manifest themselves when supporting the haulage drifts in the mined-out space, when sudden failures of the overhanging stratum provoke blockages of mine workings.

A number of researchers, in particular, in the work [9], considering the complete roof caving as a method to control rock pressure, recommend its use for easily caved side rocks. In this case, as noted in the research, the stability of mine workings at the mining site is ensured. However, with easily caved side rocks, as a result of a change in the stability and strength of rocks along the height of the level and in the direction of the strike of the seam, the roof or bottom is broken into blocks and caved uncontrollably. This situation leads to blockage of the stope face and haulage drift.

It is indicated in the works [10]-[12] that the method of roof control by backfilling the mined-out space with crushed rock most favourably influences on the side rocks state in the coal-rock mass. It is noted that when using this method, the side rocks failure in the stope face and blockages of mine workings at the mining site are excluded. Nevertheless, for various reasons, this method is not used in the mines of Ukraine when mining the steep coal seams. This can be explained by the additional cost for purchasing equipment for backfilling operations.

To maintain mine workings in an operating state, it is also proposed to use a hardening backfill [8]. This solution will lead to restriction of the side rocks displacement in the coalrock mass due to the minimum settling of the hardening support. At the same time, there are still unresolved issues with the regulation of the processes of hardening the backfill. The influence of hardening supports on the stability of side rocks and haulage drifts in terms of stresses concentration in the coal-rock mass is unclear.

At coal mining enterprises, to ensure the operating state of the zonal advance workings, non-pillar schemes for developing the mining sites are used or the haulage drifts are protected with coal pillars. Non-pillar methods of haulage drifts protection have been widespread until now [13]. This is conditioned by a decrease in the loss of minerals during the mining of extracted areas, a decrease in the risk of endogenous fires and sudden emissions of coal and gas.

The work [14] presents the research results of the haulage drifts stability in the case of different protection methods. To compare, the protection of advance workings with wooden structures or with coal pillars with limited dimensions is considered. According to the research results, it has been determined that in the zone of stope works influence, there is a stratification of side rocks, discontinuity of the overhanging stratum and deformation of the mine working contour. At the same time, nothing is mentioned about preventing the side rocks stratification and ensuring the stability of the advance workings behind the stope face in the mined-out space.

Ensuring the haulage drifts stability during their entire operational life guarantees the normal operation of the transport and the required amount of air for ventilating the mining sites. In the work [5], it is proposed to use rolling-on chocks from wooden sleepers to protect the haulage drifts and ensure their operating state. The use of yielding wooden structures to protect mine workings will restrict the rocks displacement on the haulage drift contour, but for this it is necessary to take into account a change in the stiffness of protective structures along the mine working length.

The experience of Ukrainian mines performance, when mining the steeply dipping seams, shows that in the practice of mining operations, they still prefer to use the method with coal pillars for protecting the haulage drifts [4], [7]. The height of the pillars, restricting the mine working from the influence of the mined-out space, is $8 \mathrm{~m}$. It is considered that with such sizes of coal pillars, the operating state of the haulage drifts is ensured. Meanwhile, protecting stump pillars with this size, especially in the zone of stope works influence, are prone to destruction and falling apart. As a result, cavities are formed above the haulage drift and the mine working stability deteriorates. Attempts to determine the changes in the intensity of the rock pressure manifestations along the length of the supported mine workings, depending from the size of the protecting pillars, are made in the work [15]. However, the results obtained do not allow to determine the general patterns of such changes. Hence, the research results cannot be used to substantiate the method for protecting the mine workings.

Analysis of the known methods for protecting the haulage drifts on a steep dip indicates their diversity. Global experience and practice of mining the steep coal seams show that when protecting the zonal advance workings with coal pillars of limited sizes, about $50 \%$ of haulage drifts are in an unsatisfactory state [7]. Non-pillar schemes for mining the mining sites, in certain mining-and-geological conditions, do not fully ensure the operating state of the zonal advance workings adjacent to the stope face [4], [5]. All this allows to assert the expediency of conducting experimental research on the haulage drifts stability in coal mines developing steeply dipping seams. 
Based on such research, it is possible to develop recommendations for ensuring the operating state of the haulage drifts, taking into account the applied methods of protection.

\subsection{Purpose and objectives of research}

The purpose of the research is to substantiate the conditions for ensuring the haulage drifts stability with different methods of protection in steeply dipping seams.

To achieve the purpose, the following research objectives are set:

- to carry out experiments in in-situ conditions, studying the rock pressure manifestations on the haulage drifts contour with different methods of protection and to assess the conditions for their maintenance in the zone of stope operations influence;

- to study the deformation characteristics of protective structures and to determine their influence on the haulage drifts stability along the length of the mining site.

\section{Materials and methods of research}

To study the peculiarities of the rock pressure manifestation along the length of the haulage drifts and determine the main factors, depending on the method of protection, and influencing the stability of mine workings, in-situ tests have been conducted at the Tsentralna Mine of the State Enterprise "Toretskvuhillia" (Toretsk, Ukraine).

In this regard, in this work, the object of research is the processes of ensuring the side rocks stability in the haulage drifts with different methods of protection in steeply dipping seams. As a consequence, in order to study the periodic nature of the rock pressure manifestations in the advance workings with different methods of protection, in-situ tests of the haulage drifts stability in the seams $1_{3}, 1_{5}$ and $1_{6}$ on the horizon of $1146 \mathrm{~m}$ have been conducted.

When observing at the experimental sites (Fig. 1), benchmarks are set along the mine working contour at specially equipped metering stations. With the help of mine surveying tape, the value of convergence of benchmarks relative to each other is determined. The measurement error is $\pm 2 \mathrm{~mm}$. The scheme of metering stations and the location of benchmarks on the haulage drift contour is presented in Figure 2.

In order to quickly assess the conditions for supporting the haulage drift along the length of the mining site, the following methodology is used: as the stope face advances, the width $B(\mathrm{~m})$ and height $H(\mathrm{~m})$ of the mine working are determined at the metering station. After such measurements are taken, the change in the cross-sectional area of the haulage drift $S\left(\mathrm{~m}^{2}\right)$ is recorded. The measurement scheme is shown in Figure $2 b$.

The mining-and-geological conditions of the experimental sites are presented in Table 1 . The values of elasticity modulus $E(\mathrm{~Pa})$ of coal seams $l_{3}, 1_{5}$ and $l_{6}$ are presented in Table 2 .

Haulage drift along the seam $1_{3}$. Mine working is protected with rolling-on chocks from wooden sleepers. After a while, the protection method is changed to coal pillars. Cross-sectional area of the drift $S=8.5 \mathrm{~m}^{2}$. Distance between arch support frames (AP-3) with wooden lagging $0.8 \mathrm{~m}$. Velocity of haulage drift mining $V_{h}=16 \mathrm{~m} / \mathrm{month}$, stope operations $V_{s t}=10 \mathrm{~m} /$ month. The drift is developed using drilling-and-blasting operations. Roof control method in stope face is complete caving.

Haulage drift along the seam $1_{5}$. Mine working is protected with rolling-on chocks from sleepers, then by clumps of prop stays or by coal pillars. (a)

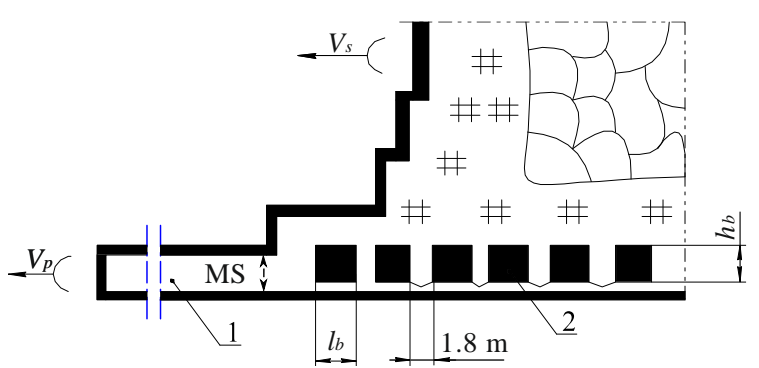

(b)

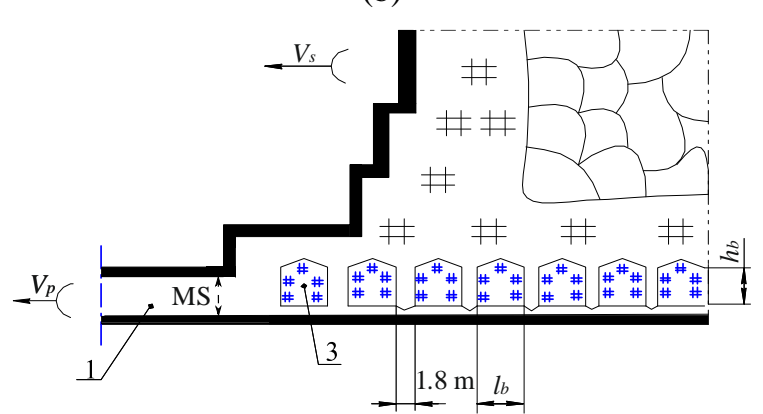

(c)

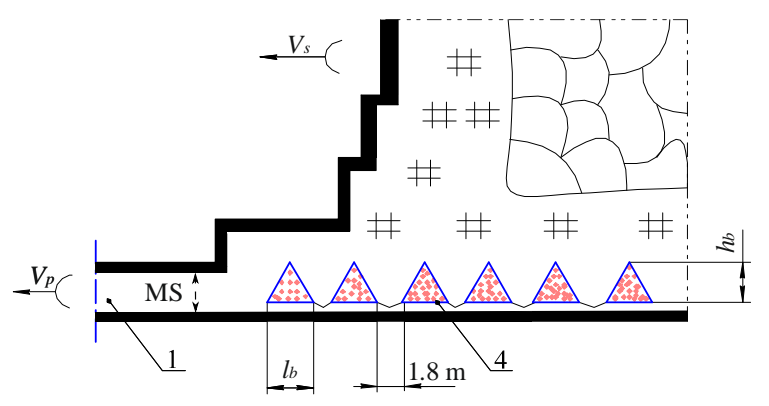

Figure 1. Scheme of experimental sites for determining the side rocks displacement on the contour and a change in the cross-sectional area of the haulage drift: (a) with the method of protecting with coal pillars; (b) with the method of protecting with rolling-on chocks from wooden sleepers; (c) with the method of protecting with clumps of prop stays: 1 - haulage drift; 2 -coal pillars; 3 -rolling-on chocks from wooden sleepers; 4 -clumps of prop stays; $h=8 m$-pillar height, $m ; l=5 m$-pillar length, $m ; h=6 m-$ rolling-on chock height, $m ; l=5 m-$ rolling-on chock width, $m ; h=3 m$ - clump height, $m$; $l=3 m$-clump width, $m ; V_{s}, V_{p}$-direction of stope and preparatory operations; $M S$ - metering stations
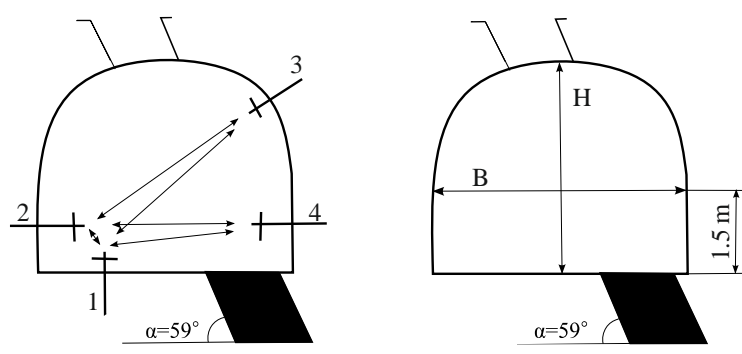

Figure 2. Scheme of the metering station for determining the side rocks displacement on the contour of the haulage drift (a) and a change in the cross-sectional area of the advance working along the length of the mining site $(b): 1,2,3,4-$ benchmarks, 1-2, 1-3, 1-4, 2-3 - benchmark displacements 1, 2 towards 3, 4; $\mathrm{H}$ - mine working height, $\mathrm{m} ; \mathrm{B}$ - mine working width, $m ; \alpha=59^{\circ}$-angle of seam inclination, deg 
Table 1. Mining-and-geological conditions of the experimental sites

\begin{tabular}{|c|c|c|c|c|c|c|}
\hline \multirow{3}{*}{$\begin{array}{l}\text { Seam } \\
\text { index }\end{array}$} & \multirow{3}{*}{$\begin{array}{l}\text { Inclination } \\
\text { angle } \alpha, \\
\text { deg }\end{array}$} & \multirow{3}{*}{$\begin{array}{c}\text { Thickness } \\
m, \mathrm{~m}\end{array}$} & \multicolumn{4}{|c|}{ Side rocks } \\
\hline & & & \multicolumn{2}{|c|}{ roof } & \multicolumn{2}{|c|}{ bottom } \\
\hline & & & immediate & main & immediate & main \\
\hline $1_{3}$ & 59 & 1.05 & $\begin{array}{l}\text { Clay shale, thickness } \\
\text { up to } m=4.0 \mathrm{~m}\end{array}$ & $\begin{array}{c}\text { Sandy shale, thickness } \\
\text { up to } m=7.0 \mathrm{~m}\end{array}$ & Clay shale & $\begin{array}{l}\text { Clay shale, thickness } \\
\text { up to } m=15 \mathrm{~m}\end{array}$ \\
\hline 15 & 59 & 0.6 & $\begin{array}{l}\text { Clay shale, thickness } \\
\text { up to } m=1.7-2.5 \mathrm{~m}\end{array}$ & $\begin{array}{l}\text { Clay shale, thickness } \\
\text { up to } m=10 \mathrm{~m}\end{array}$ & $\begin{array}{l}\text { Clay shale, sandy shale, } \\
\text { thickness of } m=2.0 \mathrm{~m}\end{array}$ & $\begin{array}{c}\text { Sandstone, thickness } \\
m=10 \mathrm{~m}\end{array}$ \\
\hline 16 & 59 & 0.62 & $\begin{array}{l}\text { Clay shale, thickness } \\
\text { up to } m=1.1 \mathrm{~m}\end{array}$ & $\begin{array}{l}\text { Clay shale, thickness } \\
\text { up to } m=8-10 \mathrm{~m}\end{array}$ & $\begin{array}{c}\text { Clay shale, thickness up } \\
\text { to } m=0.8-2.5 \mathrm{~m}\end{array}$ & $\begin{array}{l}\text { Clay shale, thickness } \\
\text { up to } m=2.5-4.4 \mathrm{~m}\end{array}$ \\
\hline
\end{tabular}

Table 2. Values of the coal seam elasticity modulus $\mathrm{E}(\mathrm{Pa})$

\begin{tabular}{cc}
\hline Seam index & Elasticity modulus $E(\mathrm{~Pa})$ \\
\hline$l_{3}$ & $0.29 \cdot 10^{10}$ \\
\hline$l_{5}$ & $0.33 \cdot 10^{10}$ \\
\hline$l_{6}$ & $0.31 \cdot 10^{10}$ \\
\hline
\end{tabular}

Cross-sectional area of the haulage drift $S=8.5 \mathrm{~m}^{2}$. Distance between arch support frames (AP-3) with wooden lagging $0.8 \mathrm{~m}$. Velocity of haulage drift mining $V_{h}=14 \mathrm{~m} / \mathrm{month}$, stope operations $V_{s t}=11 \mathrm{~m} / \mathrm{month}$. The drift is developed using drilling-and-blasting operations. Roof control method in stope face is complete caving.

Haulage drift along the seam $1_{3}$. Mine working is protected with rolling-on chocks from wooden sleepers. After a while, the protection method is changed to coal pillars. Cross-sectional area of the drift $S=8.5 \mathrm{~m}^{2}$. Distance between arch support frames (AP-3) with wooden lagging $0.8 \mathrm{~m}$. Velocity of haulage drift mining $V_{h}=16 \mathrm{~m} / \mathrm{month}$, stope operations $V_{s t}=10 \mathrm{~m} / \mathrm{month}$. The drift is developed using drilling-and-blasting operations. Roof control method in stope face is complete caving.

Haulage drift along the seam $1_{5}$. Mine working is protected with rolling-on chocks from sleepers, then by clumps of prop stays or by coal pillars. Cross-sectional area of the haulage drift $S=8.5 \mathrm{~m}^{2}$. Distance between arch support frames (AP-3) with wooden lagging $0.8 \mathrm{~m}$. Velocity of haulage drift mining $V_{h}=14 \mathrm{~m} / \mathrm{month}$, stope operations $V_{s t}=11 \mathrm{~m} / \mathrm{month}$. The drift is developed using drilling-and-blasting operations. Roof control method in stope face is complete caving.

Haulage drift along the seam $\mathrm{l}_{6}$. Mine working is protected with coal pillars. Cross-sectional area of the haulage drift $S=8.5 \mathrm{~m}^{2}$. Distance between arch support frames (AP-3) with wooden lagging $0.8 \mathrm{~m}$. Velocity of haulage drift mining $V_{h}=12 \mathrm{~m} /$ month, stope operations $V_{s t}=8 \mathrm{~m} /$ month. The drift is developed using drilling-and-blasting operations. Roof control method in stope face is complete caving. The dimensions of the protective structures are shown in Figure 1.

In the real conditions of mining the steep coal seams, with different methods of controlling the rock pressure in the stope face, the safety of the haulage drift is ensured due to the side rocks stability. In this case, in order to maintain the integrity of the stratum overhanging the in-seam advance working, protective structures are erected - coal pillars or wooden structures.

The load $P(\mathrm{H})$ on the protective structure is determined from Hooke's law [16], [17]:

$$
P=E \cdot S \cdot \frac{\Delta h}{h}
$$

where:

$$
E \text { - elasticity modulus, } \mathrm{Pa} \text {; }
$$

$S$-cross-sectional area of the protective structure per 1 running meter of the haulage drift, $\mathrm{m}^{2}$ : for pillars $S=8 \mathrm{~m}^{2}$; for rolling-on chocks $S=6 \mathrm{~m}^{2}$; for clumps $S=3 \mathrm{~m}^{2}$; ratio $\Delta h / h$ is a relative deformation of the protective structure, that is:

$\varepsilon=\frac{\Delta h}{h}$,

where:

$\Delta h$ - vertical convergence according to measurements in the drift, m;

$h$-protective structure height (corresponds to the coal seam thickness), $\mathrm{m}$.

In this research, we take the change in the distance between benchmarks 1 and 3 on the haulage drift contour as the value $\Delta h(\mathrm{~m})$ :

$$
\Delta h=u_{1-3} \text {. }
$$

As a simple and, at the same time, illustrating indicator of the analysis of the haulage drifts stability taking into account the rock displacements on the contour and the deformation properties of protective structures, we use an assessment of the increment of roof displacements $\Delta u(m)$ on the haulage drift contour with different protection methods with distance from the stope face, determined as:

$$
\Delta u=u_{(1-3) i}-u_{(1-3) i-1} \text {. }
$$

To smooth out short-term fluctuations and identify characteristic trends in changes of the studied parameter, the method of simple sliding average [18], [19] is applied with an averaging period 2:

$$
\overline{\Delta u}=\frac{\Delta u_{i}-\Delta u_{i-1}}{2} \text {. }
$$

Currently, wood is the most common fastening material in mines when using non-pillar methods of mine working protection. The strength of wood varies widely, depending on the nature and direction of the load. Therefore, it is supposed that when using the rolling-on chocks from wooden sleepers, their compression occurs across the fibres. In the case when clumps of prop stays are used to protect mine workings, the compression of such wooden structures occurs along the fibres. The action of compressive forces along or across the fibres determines the value of elasticity modulus $E$ (Pa) of wooden specimens [20], [21].

The values of elasticity modulus $E(\mathrm{~Pa})$ of protective structures made of wood are presented in Table 3. It should be noted that the protective structures above the drift designed to support the side rocks behind the stope face are specific objects along the entire length of the mining site. 
Table 3. Values of elasticity modulus $E$ (Pa) of protective structures

\begin{tabular}{lc}
\hline \multicolumn{1}{c}{ Protective structure } & Elasticity modulus $E(\mathrm{~Pa})$ \\
\hline $\begin{array}{l}\text { Rolling-on chocks from } \\
\text { wooden sleepers }\end{array}$ & $520 \cdot 10^{6}$ \\
\hline Clumps of wooden prop stays & $12600 \cdot 10^{6}$ \\
\hline
\end{tabular}

The deformation characteristics of such objects depend on a large number of factors. In order to assess the conditions for supporting the haulage drifts with different methods of protection, experimental data are used on the side rocks convergence and the increment of displacements along the length of the haulage drift. Taking into account the calculated load on the protective structures $P(\mathrm{H})$ and the value of their relative deformation $\varepsilon$, it is possible to obtain a real assessment of the deformation properties of coal pillars, rolling-on chocks from sleepers and clumps of prop stays, and, therefore, to assess the conditions for supporting the haulage drifts.

\section{Results}

\subsection{Rock pressure manifestations on the haulage drift contour with different protection methods}

When performing in-situ measurements, the main attention is paid to the side rocks displacement $u(\mathrm{~mm})$ on the mine working contour with different methods of protection, depending on the distance to the stope face along the length of the haulage drift $l(\mathrm{~m})$ at the mining site.

Based on the results of in-situ tests, graphs are plotted of the side rock displacements $u(\mathrm{~mm})$ on the contour of the haulage drift of seams $1_{3}, 1_{5}$ and $1_{6}$ while protecting with coal pillars along the mining site length $l$ (m) (Fig. 3).

In all cases, when protecting the haulage drift with coal pillars, the rock displacements from the bottom side are insignificant and range $u_{1-4}=110-140 \mathrm{~mm}$ (Fig. 3a, b).

Figure $3 \mathrm{a}$ presents the graphs of side rock displacements $u$ $(\mathrm{mm})$ on the haulage drift contour of the seam $1_{3}$. It can be seen from the graphs that the greatest side rock displacements on the haulage drift contour are recorded in the direction of benchmarks 1-3 and 2-3. In quantitative terms, the maximum set value of displacements $u(\mathrm{~mm})$ at a distance of $l=100 \mathrm{~m}$ behind the stope face is $u_{1-3}=510 \mathrm{~mm}$ and $u_{2-3}=390 \mathrm{~mm}$.

Figure $3 \mathrm{~b}$ presents the graphs of side rock displacements $u(\mathrm{~mm})$ on the haulage drift contour of the seam $1_{5}$. During the experiments, it is noted that the greatest side rock displacements take place from the side of the roof, in the direction of benchmarks 1-3 and 2-3. The value of displacements $u(\mathrm{~mm})$ at a distance of $l=100 \mathrm{~m}$ behind the stope face is for benchmarks 1-3 $u_{1-3}=450 \mathrm{~mm}$ and for benchmarks 2-3 $u_{2-3}=310 \mathrm{~mm}$.

Figure $3 \mathrm{c}$ presents the graphs of side rock displacements $u(\mathrm{~mm})$ on the haulage drift contour of the seam $1_{6}$ along the mining site length $l(\mathrm{~m})$. Based on the results of in-situ tests, by measuring the benchmarks convergence in the haulage drift, the maximum side rock displacements are determined at a distance of $l=100 \mathrm{~m}$ behind the stope face. In the direction of benchmarks 1-3 and 2-3, these displacements are $u_{1}$ ${ }_{3}=490 \mathrm{~mm}$ and $u_{2-3}=280 \mathrm{~mm}$.

Figure 4 presents the graphs of side rock displacements $u$ $(\mathrm{mm})$ on the haulage drift contour of the seams $1_{5}$ and $1_{6}$ along the mining site length $l(\mathrm{~m})$. As a result of the tests performed, it has been determined that the greatest rock displacements are recorded by benchmarks 1-3 and 2-3, which reflect the displacements of the roof rocks. (a)

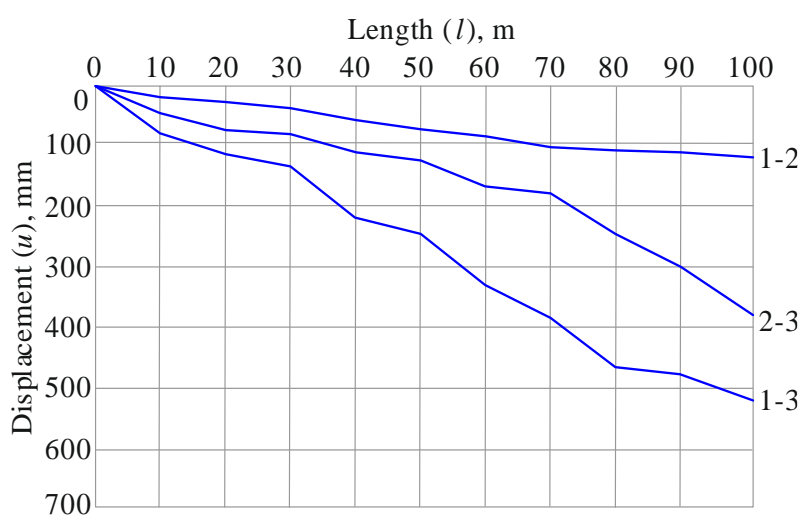

(b)

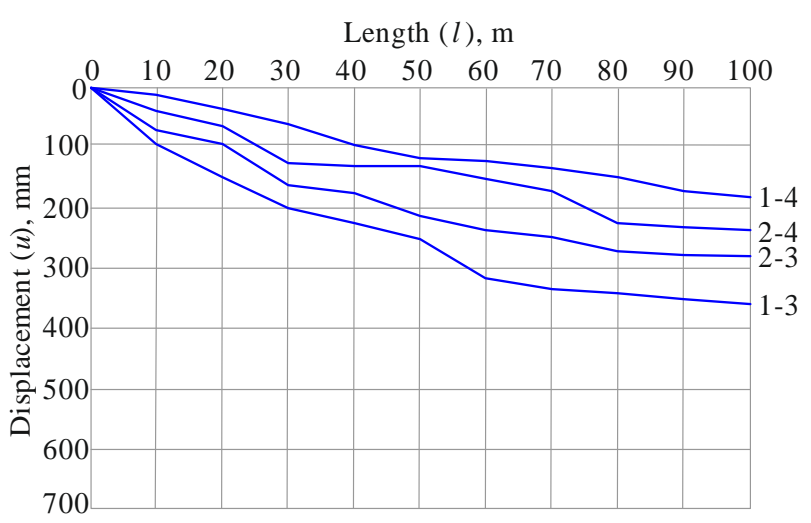

(c)

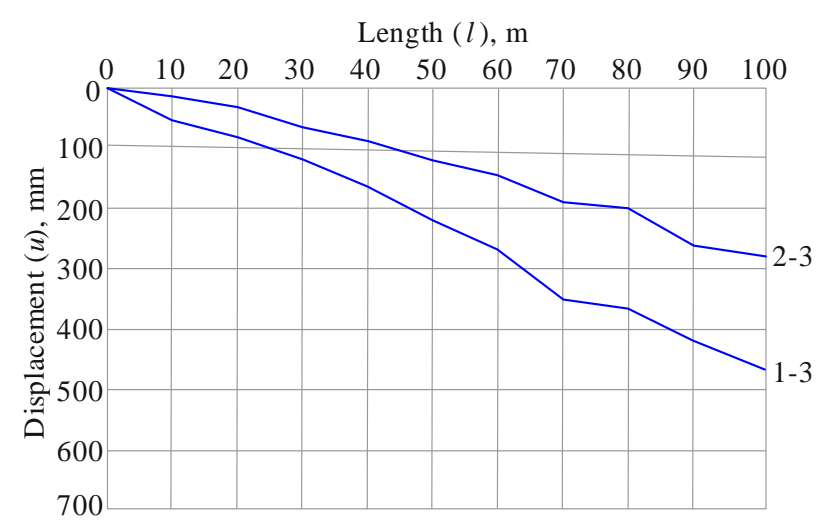

Figure 3. Graphs of side rock displacements $u(\mathrm{~mm})$ on the haulage drift contour when protecting with coal pillars along the mining site length $l(m):$ (a) haulage drift on the seam $l_{3}$; (b) haulage drift on the seam $l_{5}$; (c) haulage drift on the seam $l_{6} ; 1-2 ; 2-3 ; 1-3 ; 1-4$-benchmark displacements 1, 2 towards the benchmarks 2, 3, 4 on the mine working contour

The value of the roof displacements on the haulage drift contour at a distance of $l=60 \mathrm{~m}$ behind the stope face is on the seam $1_{5} u_{1-3}=350 \mathrm{~mm}$ and $u_{2-3}=200 \mathrm{~mm}$ (Fig. 4a). For the seam $1_{6}$, the displacements of the roof rocks at the same distance are equal to $u_{1-3}=320 \mathrm{~mm}$ and $u_{2-3}=50 \mathrm{~mm}$ (Fig. 4b). At a distance of $l>60 \mathrm{~m}$, the side rocks convergence noticeably decreases. The roof rock displacements at a distance of $l=100 \mathrm{~m}$ behind the stope face are for the seam $1_{5} u_{1-3}=390 \mathrm{~mm}$ and $u_{2-3}=250 \mathrm{~mm}$ (Fig. 4a), and for the seam $\mathrm{l}_{6}-u_{1-3}=380 \mathrm{~mm}$ and $u_{2-3}=280 \mathrm{~m}$ (Fig. $4 \mathrm{~b}$ ). 
(a)

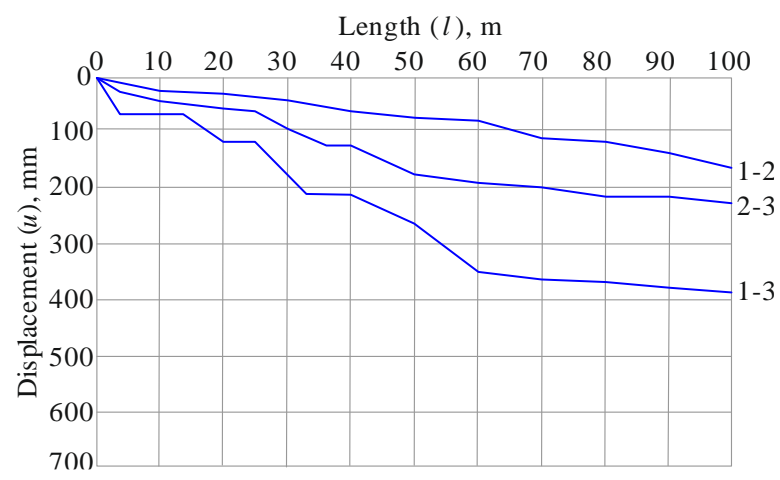

(b)

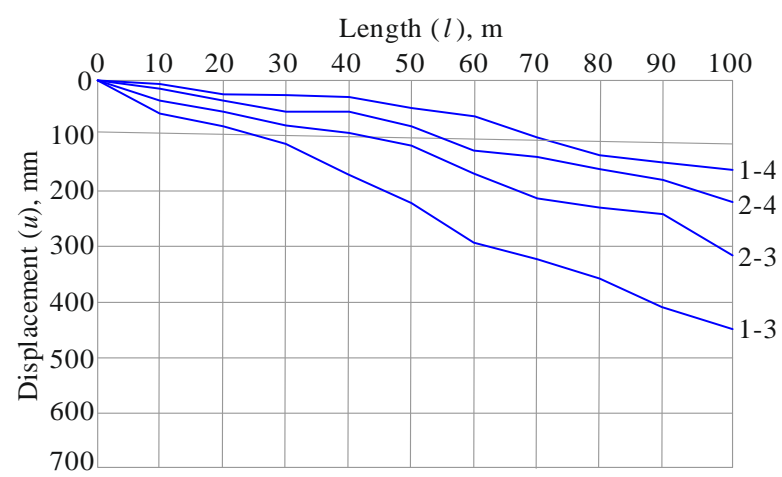

Figure 4. Graphs of side rock displacements $\boldsymbol{u}(\mathrm{mm})$ on the haulage drift contour when protecting with rolling-on chocks from wooden sleepers along the mining site length $l(m)$ : (a) haulage drift on the seam $l_{5}$; (b) haulage drift on the seam $l_{6} ; 1-2 ; 1-3 ; 2-3 ; 2-4$ - benchmark displacements 1, 2 towards the benchmarks 3, 4

Figure 5 presents the graphs of side rock displacements $u$ $(\mathrm{mm})$ on the haulage drift contour of the seam 15 when protecting with clumps of wooden prop stays along the mining site length $l(\mathrm{~m})$. It can be seen from the graphs that the maximum side rock displacements on the haulage drift contour take place from the side of the roof in the direction of benchmarks 1-3 and 2-3. At a distance of $l>60 \mathrm{~m}$ behind the stope face, the roof displacements exceed the structural yielding property of support in the drift. The roof displacements reach the value $u_{1-3}=350-440 \mathrm{~mm}$ and increase. At a distance of $l=100 \mathrm{~m}$, rock displacements by benchmarks $1-3$ and 2-3 are $u_{1-3}=560 \mathrm{~mm}$ and $u_{2-3}=470 \mathrm{~mm}$, respectively. The bottom rock displacements are $u_{1-4}=210 \mathrm{~mm}$.

During observations of rocks displacement on the haulage drift contour, a decrease in the cross-sectional area of mine workings along the mining site length is also recorded.

\subsection{Determining the deformation properties of protective structures above the drift}

In order to assess the conditions for supporting zonal advance workings with different methods of protection, especially in the zone of stope works influence, it is necessary to jointly consider the issues of the haulage drifts stability and the operability of protective structures. This approach will make it possible to determine the patterns of haulage drifts deformation behind the stope face, to substantiate the rational parameters of protective structures. For this purpose, along with the registration of the side rocks convergence on the advance working contour, as the stope face advances, the change in the cross-sectional area $S\left(\mathrm{~m}^{2}\right)$ of the haulage drift is recorded.

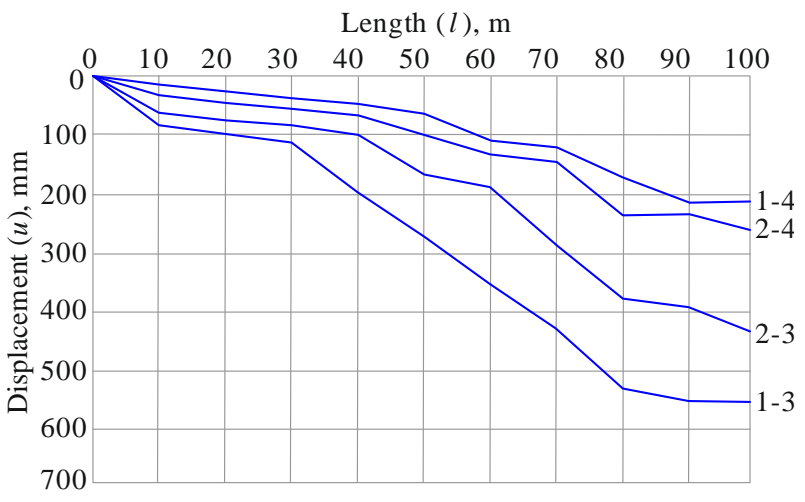

Figure 5. Graphs of side rock displacements $u(\mathrm{~mm})$ on the haulage drift contour of the seam $l_{5}$ when protecting with clumps of wooden prop stays along the mining site length $l(m)$ : 1-4; 2-4; 2-3; 1-3 - benchmark displacements 1, 2 towards benchmarks 3, 4

Figure 6 shows the graphs of the change in the value of $S\left(\mathrm{~m}^{2}\right)$ along the mining site length $l(\mathrm{~m})$ with different methods of protection. Figure 6a shows the graphs of the change in the value of $S\left(\mathrm{~m}^{2}\right)$ of the haulage drift along the mining site length $l(\mathrm{~m})$, when the advance working is driven on the seam $\mathrm{l}_{3}$. From the presented graphs it can be seen that when the drift is protected with coal pillars, the mine working section changes from $S=8.5 \mathrm{~m}^{2}$ to $S=4.1 \mathrm{~m}^{2}$ at a distance of $l=100 \mathrm{~m}$ behind the stope face. The decrease in the section is about $52 \%$ of the initial $\left(S=8.5 \mathrm{~m}^{2}\right)$, recorded at the conjugation of the haulage drift with the stope face of the seam $1_{3}$. When using rolling-on chocks from wooden sleepers to protect the haulage drift, the mine working section at a distance of $l=100 \mathrm{~m}$ decreases to $S=6.0 \mathrm{~m}^{2}$. In this case, the area loss is $30 \%$.

Figure $6 \mathrm{~b}$ shows the graphs of the change in the value of $S\left(\mathrm{~m}^{2}\right)$ along the mining site length $l(\mathrm{~m})$, when the haulage drift is driven on the seam $1_{5}$. In the case when mine working is protected with coal pillars, the drift section changes from $S=8.5 \mathrm{~m}^{2}$ to $S=3.95 \mathrm{~m}^{2}$ at a distance of $l=100 \mathrm{~m}$ behind the stope face. The cross-sectional area loss is $54 \%$. When the haulage drift is protected with rolling-on chocks from sleepers, the drift section decreases from $S=8.5 \mathrm{~m}^{2}$ to $S=5.8 \mathrm{~m}^{2}$ at a distance of $l=100 \mathrm{~m}$. The area loss is $32 \%$.

The use of clumps of prop stays for protecting the haulage drift leads to a situation when the advance working section decreases from $S=8.2 \mathrm{~m}^{2}$ to $S=3.8 \mathrm{~m}^{2}$ at a distance of $l=100 \mathrm{~m}$ behind the stope face. Loss of the drift crosssectional area is 53\% (Fig. 6b). When protecting the haulage drift of the seam $1_{5}$ with coal pillars, the drift section decreases from $S=8.4 \mathrm{~m}^{2}$ to $S=4.0 \mathrm{~m}^{2}$ at a distance of $l=100 \mathrm{~m}$ behind the stope face. The reduction in the cross-sectional area of the drift is $53 \%$ of the initial one (Fig. 6c).

As a result of performed measurements of the height $H$ and width $B$ of mine working along the mining site length $l$, it has been determined that the support in the haulage drift has characteristic bends and is deformed from the roof side.

Figure 7 shows the graphs of changes in the calculated load on protective structures $P(\mathrm{MN})$ along the experimental site length $l(\mathrm{~m})$. It can be seen from the graphs that when the haulage drift is protected with coal pillars, the calculated load increases in stages. Thus, at a distance $l=10-30 \mathrm{~m}$ behind the stope face, an insignificant increase in the load is noted when $P=3.1-4.9 \mathrm{MN}$. At a distance of $l=100 \mathrm{~m}$, the load on the pillar increases to values of $P=12-19 \mathrm{MN}$ (Fig. 7, graphs 1.1; 1.2; 1.3). 
(a)

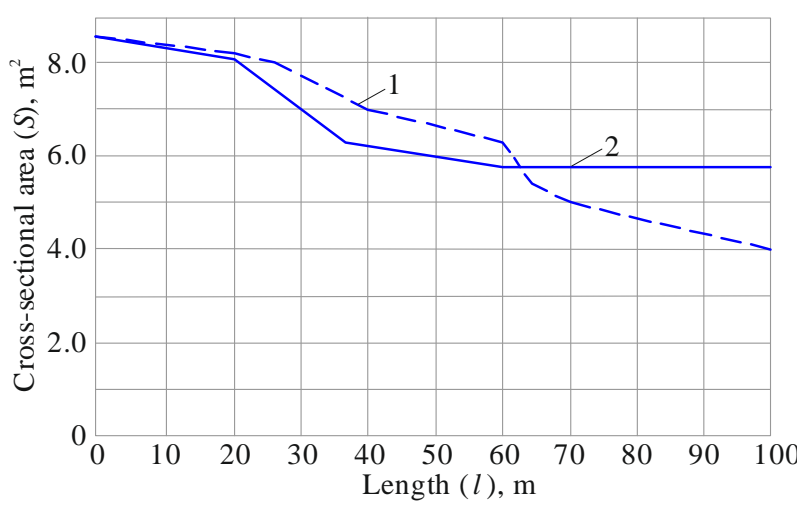

(b)

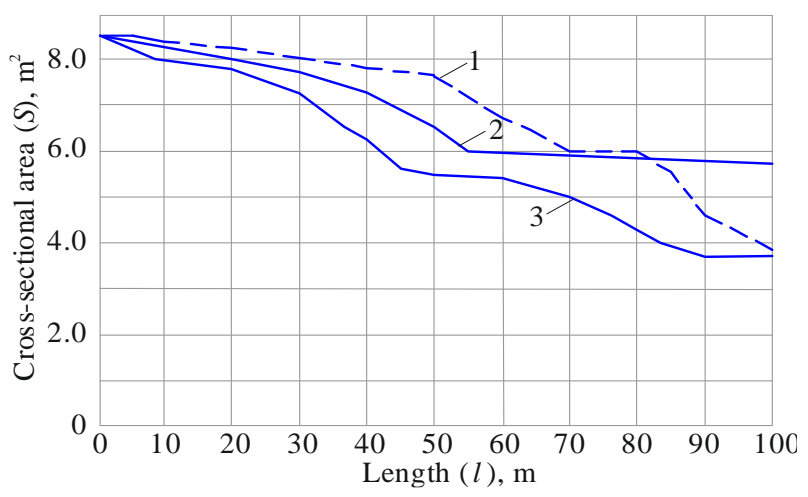

(c)

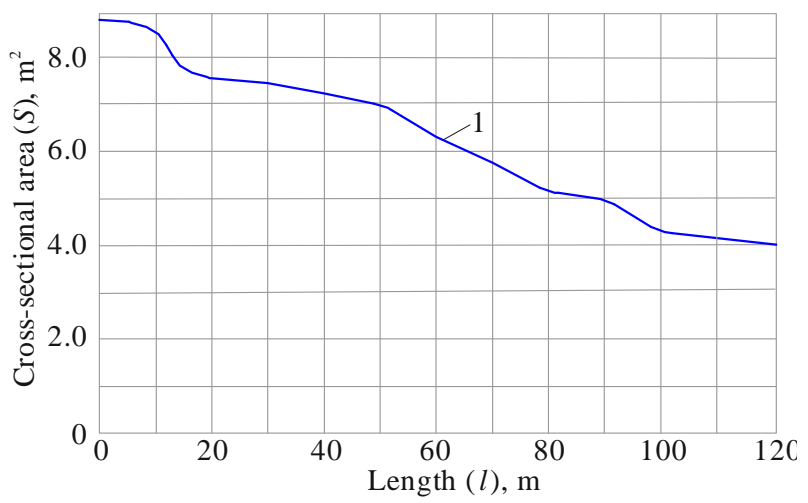

Figure 6. Graphs of the change in the cross-sectional area of the haulage drift $S\left(\mathrm{~m}^{2}\right)$ along the mining site length $l(\mathrm{~m})$ with different methods of protection: (a) haulage drift on the seam $l_{3}$; (b) haulage drift on the seam $l_{5}$; (c) haulage drift on the seam $l_{6} ; 1$-coal pillars; 2- rolling-on chocks from wooden sleepers; 3 - clumps of prop stays

When protecting the haulage drift with rolling-on chocks from sleepers, the load increases smoothly and reaches maximum values of $P=2.5-3.0 \mathrm{MN}$ at a distance of $l=60 \mathrm{~m}$ behind the stope face. Further, an increase in the calculated load $P$ is insignificant (Fig. 7, graphs 2.2; 2.3).

When protecting the haulage drift with clumps of prop stays, the load increases in stages. Thus, at a distance of $l=30 \mathrm{~m}$ behind the stope face, the calculated load on the clumps of prop stays corresponds to $P=7.5 \mathrm{MN}$. At a distance of $l=30-80 \mathrm{~m}$, an increase in the load up to $P=33 \mathrm{MN}$ is observed. The maximum values of the load $P=34.5 \mathrm{MN}$ are noted at a distance of $l=100 \mathrm{~m}$ behind the stope face (Fig. 7, graph 3.2).

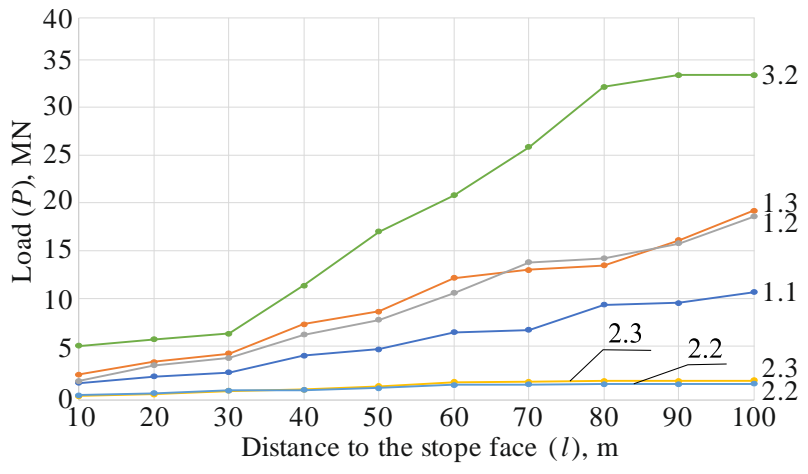

Figure 7. Graphs of the change in the calculated load on protective structure along the haulage drift length $l(m)$ with different methods of protection: 1.1; 1.2; 1.3 - coal pillars; 2.2; 2.3 - rolling-on chocks from wooden sleepers; 3.2 - clumps of prop stays: 1.1 - seam $l 3 ; 1.2 ; 2.2 ; 3.2$ seam $l 5 ; 1.3 ; 2.3-$ seam $l_{6}$

Figure 8 shows the graphs of the change in the relative deformation $\varepsilon$ of protective structures located above the haulage drift along the experimental site length $l(\mathrm{~m})$.

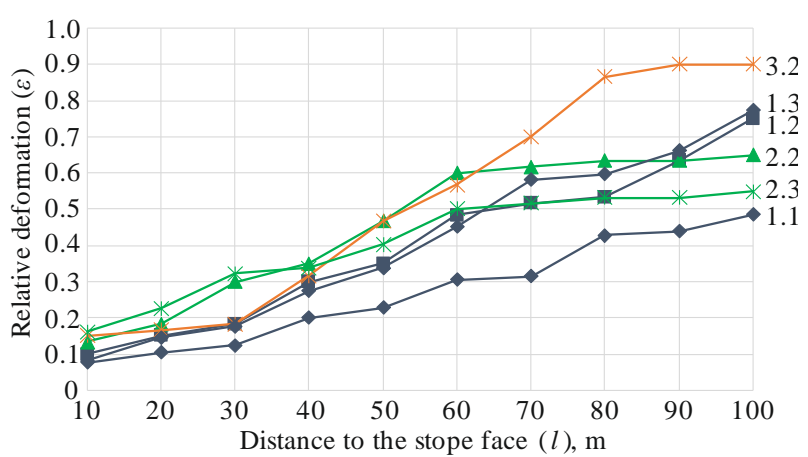

Figure 8. Graphs of the change in the relative deformation $\varepsilon$ of protective structures depending on the distance to the stope face $l(m)$ with different methods of protecting the haulage drift: $1.1 ; 1.2 ; 1.3$ - coal pillars; $2.2 ; 2.3$ - rolling-on chocks from wooden sleepers; 3.2 - clumps of prop stays: 1.1 -seam $l_{3} ; 1.2 ; 2.2 ; 3.2-$ seam $l_{5} ; 1.3 ; 2.3-$ seam $l_{6}$

It can be seen from the presented graphs that when the haulage drift is protected with coal pillars, the value of the relative deformation $\varepsilon$ increases with an increase in the length $l$ of the experimental site. The maximum values of the relative deformation $\varepsilon$ of coal pillars are recorded at a distance of $l=100 \mathrm{~m}$ behind the stope face. Thus, for coal pillars, left to protect the haulage drift of the seam $1_{3}$, the values of the relative deformation correspond to $\varepsilon=0.49$ (Fig. 8, graph 1.1). To protecting pillars of the haulage drift of seam $1_{5}$, this value is equal to $\varepsilon=0.75$ (Fig. 8 , graph 1.2), and for seam $\mathrm{l}_{6}-\varepsilon=0.77$ (Fig. 8, graph 1.3).

When protecting the haulage drift with rolling-on chocks from wooden sleepers, an increase in relative deformation is recorded at a distance of $l=10-60 \mathrm{~m}$ behind the stope face. Moreover, for the seam $1_{5}$, the value of $\varepsilon=0.6$, and for the seam $1_{6}-\varepsilon=0.5$, at a distance of $l=60 \mathrm{~m}$ (Fig. 8, graphs 2.2 and 2.3). With an increase in the experimental site length to $l=100 \mathrm{~m}$, the values of the relative deformation of the rollingon chocks increase insignificantly and are equal to $\varepsilon=0.65$ for seam $1_{5}$ and $\varepsilon=0.55$ - for seam $l_{6}$ (Fig. 8, graphs 2.2 and 2.3).

When protecting the haulage drift with clumps of prop stays, at a distance of $l=10-30 \mathrm{~m}$ the value of the relative de- 
formation corresponds to $\varepsilon=0.19$. With the distance from the stope face, that is, at a distance of $l=80 \mathrm{~m}$, the value of the relative deformation increases to $\varepsilon=0.88$. The maximum values of the studied parameter, equal to $\varepsilon=0.9$, are recorded at a distance of $l=100 \mathrm{~m}$ behind the stope face (Fig. 8, graph 3.2).

Figures 9-11 show graphs of the change in the increment of roof rock displacements $\Delta u$ on the haulage drift contour with different protection methods with an increase in the relative deformation $\varepsilon$ of protective structures.

(a)

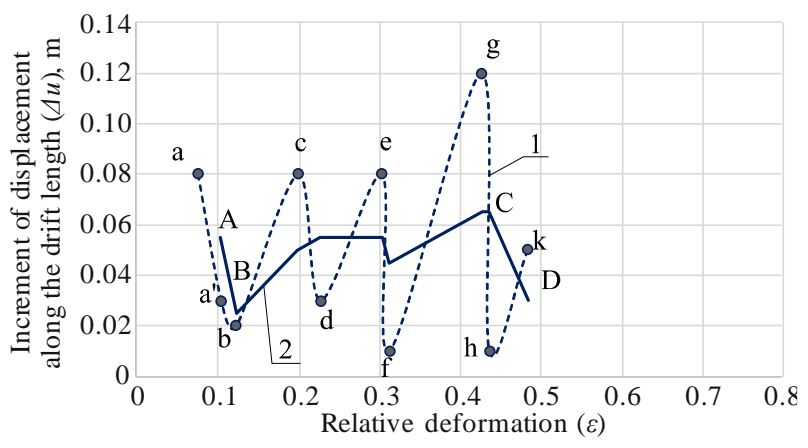

(b)

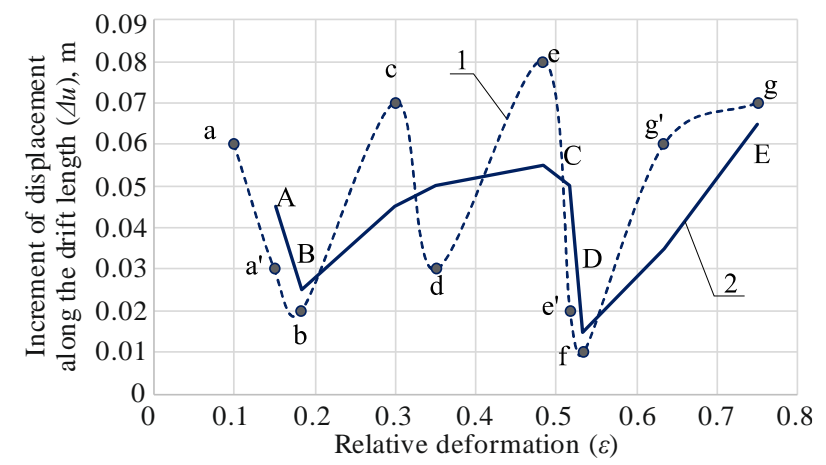

(c)

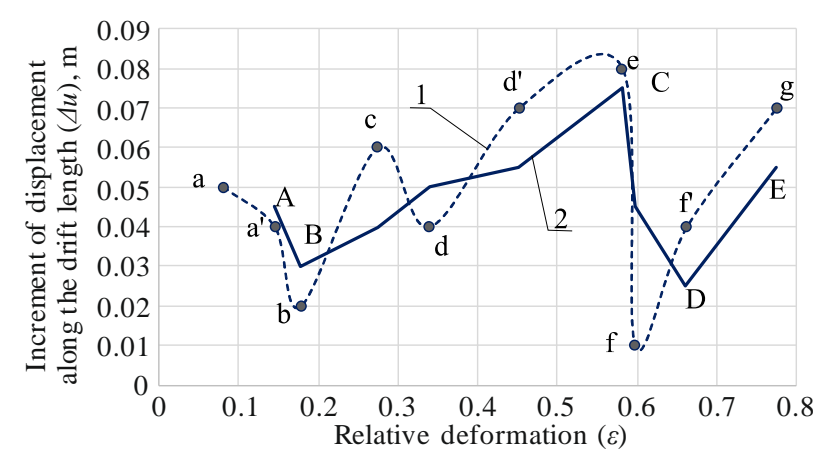

Figure 9. Graphs of the change in the increment of displacements $\Delta u(m)$ on the haulage drift contour depending on the relative deformation $\varepsilon$ of the stump coal pillars: (a) haulage drift on the seam $l_{3}$; (b) haulage drift on the seam $l_{5} ;(c)$ haulage drift on the seam $l_{6}: 1$-a change in the increment of roof displacements $\Delta u$ on the haulage drift contour; 2 - sliding average

It can be seen from the graphs above that the stump coal pillar after unloading of the coal-rock mass is deformed under external forces. As a result of this interaction of side rocks with protective structures above the drift, the increment of displacements $\Delta u$ on the haulage drift contour with an increase in the relative deformation $\varepsilon$ of the latter, increases or decreases as the length of the mining site changes (Fig. 9-11).
When protecting the haulage drift with coal pillars, as can be seen from the graph in Figure 9, in the initial deformation zone A-B (along the sliding average), with an increase in the relative deformation $\varepsilon$, the resistance of the coal pillar increases. This process is characterized by a decrease in the value of the increment of the roof displacements $\Delta u$ on the mine working contour. It is recorded that with an increase in the relative deformation of the coal pillar of the seam $l_{3}$ from $\varepsilon=0.1$ to $\varepsilon=0.12$, the increment of the roof displacements decreases from $\Delta u=0.08 \mathrm{~m}$ to $\Delta u=0.02 \mathrm{~m}$ (Fig. 9a). For a coal pillar of the seam $1_{5}$, when the value of the relative deformation changes from $\varepsilon=0.1$ to $\varepsilon=0.18$, the value of $\Delta u$ decreases from 0.06 to $0.02 \mathrm{~m}$ (Fig. $9 \mathrm{~b}$ ). For a coal pillar of the seam $1_{6}$, a change in the value of the relative deformation from $\varepsilon=0.09$ to $\varepsilon=0.19$ is accompanied by a decrease in the increment of displacements from $\Delta u=0.05 \mathrm{~m}$ to $\Delta u=0.02 \mathrm{~m}$ (Fig. 9c).

A sharp drop in the resistance of coal pillars with an increase in the increment of roof displacements $\Delta u$ is recorded in the zone b-c. This process is caused by the beginning of gradual fracturing in pillars and is accompanied by an increase in relative deformation $\varepsilon$. Thus, for a coal pillar of the seam $1_{3}$, with an increase in the relative deformation from $\varepsilon=0.12$ to $\varepsilon=0.2$, the increment of roof displacements increases from $\Delta u=0.02 \mathrm{~m}$ to $\Delta u=0.082 \mathrm{~m}$ (Fig. 9a). For a coal pillar of the seam $1_{5}$, with an increase in the relative deformation from $\varepsilon=0.18$ to $\varepsilon=0.31$, the value of $\Delta u$ increases from 0.02 to $0.07 \mathrm{~m}$ (Fig. 9b). For a coal pillar of the seam $1_{6}$, a change in the relative deformation from $\varepsilon=0.19$ to $\varepsilon=0.29$ causes an increase in the increment of displacements of the roof rocks on the haulage drift contour from $\Delta u=0.02 \mathrm{~m}$ to $\Delta u=0.06 \mathrm{~m}$ (Fig. $9 \mathrm{c}$ ).

A qualitative analysis of the diagrams shown in Fig. 9 indicates that at the initial stage of deformation (zone A-B along the sliding average), the coal pillars operate in the mode of increasing resistance, with a decrease in the increment value of the roof displacements $\Delta u$. As the process of fracturing develops, the pillars begin to gradually lose their loadbearing capacity, which, against the background of periodic roof subsidence as a whole, is characterized by a gradual increase in the increment of roof displacements $\Delta u$ (zone B-C).

The maximum values of the increment in the displacements $\Delta u$ of the roof rocks on the haulage drift contour when protecting with coal pillars are noted at the maximum $\varepsilon$ values of the protective structures relative deformation. It is noted that with the coal pillar deformation of the seam $l_{3}$ by $42 \%$, the maximum increment in displacements is $\Delta u=0.08 \mathrm{~m}$ (Fig. 9a). When the coal pillar of the seam $1_{5}$ is deformed by $48 \%$, the maximum increment of displacement is $\Delta u=0.08 \mathrm{~m}$ (Fig. 9b). For a coal pillar of the seam $1_{6}$, with its deformation by $59 \%$, the maximum increment in displacements is $\Delta u=0.082 \mathrm{~m}$ (Fig. 9c).

Further deformation of the pillar leads to its complete destruction and partial falling apart with a loss of load-bearing capacity and resistance to side rocks displacement (zone D-E).

Similar dependences can be observed during the deformation of rolling-on chocks from wooden sleepers located above the haulage drift of the seams $l_{5}$ and $l_{6}$ (Fig. 10). It is seen from the presented graphs that at the initial stage of deformation (zone $\mathrm{AB}$ along the sliding average), the average increment in roof displacements $\Delta u$ is either conditionally constant (seam $1_{5}$, Fig. 10a) or gradually decreases (as in the case of deformation of the protective structure located above the haulage drift of the seam $\mathrm{l}_{6}$, from $\Delta u=0.1 \mathrm{~m}$ to $\Delta u=0.01-0.02 \mathrm{~m}$, Fig. 10b). 
(a)

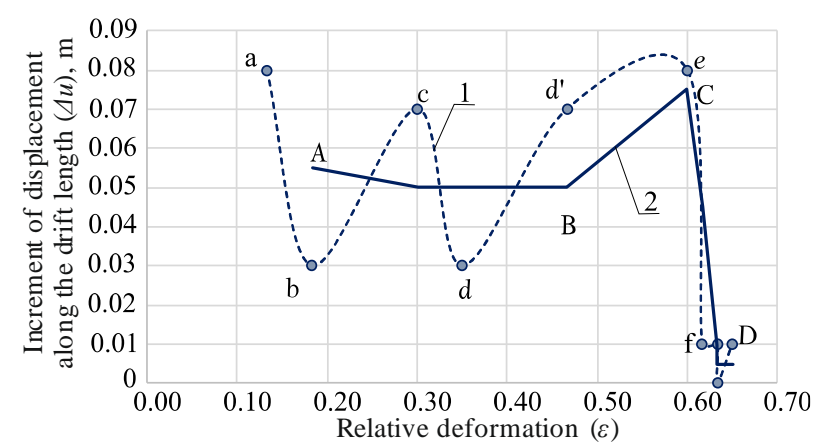

(b)

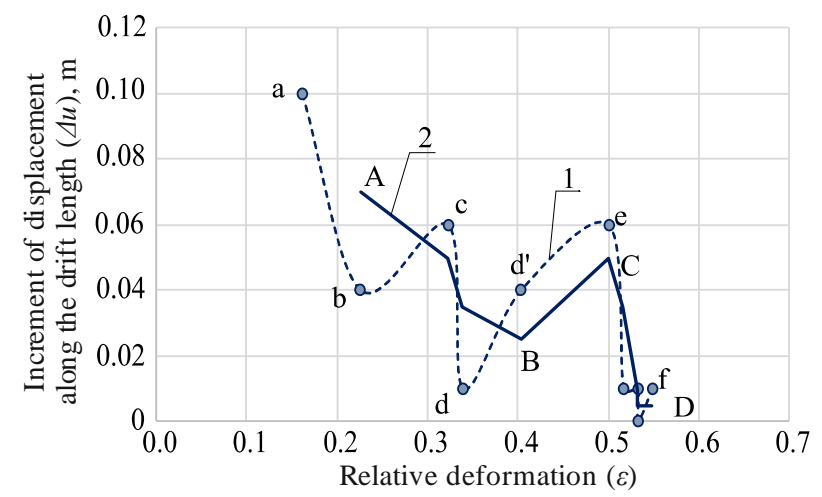

Figure 10. Graphs of the change in the increment of displacements $\Delta u(m)$ depending on the relative deformation $\varepsilon$ of the rolling-on chocks located above the haulage drift: (a) seam $l_{5}$; (b) seam $l_{6}: 1$ - a change in the increment of roof displacements $\Delta u$ on the haulage drift contour; 2 -sliding average

This testifies to the operation of protective structures in the mode of constant or slightly increasing resistance (typical for yielding and limited-yielding support structures, respectively [8], [22]).

The maximum compression of the rolling-on chocks is achieved with a relative deformation $\varepsilon=0.5-0.6$ (there is an abrupt compaction of the protective structure before that zone B-C), after which further displacements of the side rocks practically cease (zone C-D).

Deformation of clumps of prop stays used to protect the haulage drift of the seam $1_{5}$ is characterized by operation in the mode of increasing resistance (zone A-B) to the value of relative deformation $\varepsilon=0.16-0.19$, followed by destruction of prop stays and loss of load-bearing capacity. This is accompanied by an uncontrolled increase in displacements (zone B-C) until almost complete convergence of the side rocks (zone $\mathrm{C}-\mathrm{D}$ ). The average value of the increment in displacements in the B-C zone is the highest of the compared methods of protecting the haulage drifts $(\Delta u=0.08 \mathrm{~m})$, as well as the maximum convergence of rocks $(90 \%)$ (Fig. 11).

Thus, the analysis of alternating changes in the increment of side rock displacements on the haulage drift contour and the change in the cross-sectional area of mine working along the mining site length makes possible to identify, based on data of experimental observations, the characteristic modes of protective structures operation and give a real assessment of the zonal advance workings stability with different methods of protection.

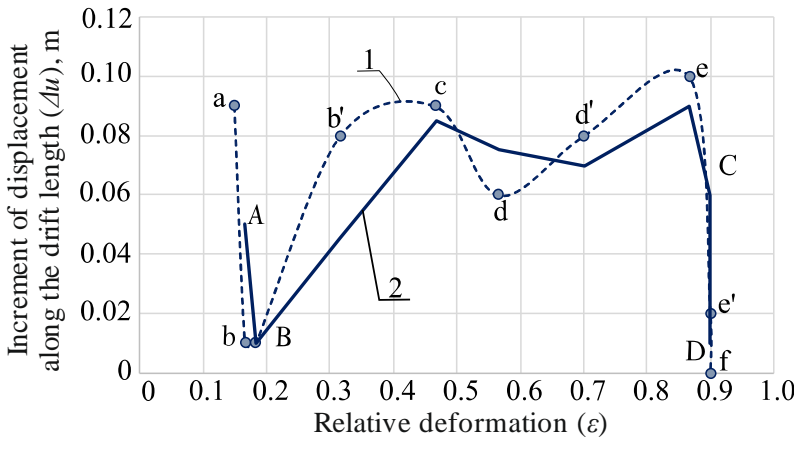

Figure 11. Graph of the change in the increment of displacements $\Delta u(m)$ depending on the relative deformation $\varepsilon$ of the protective structure (clumps of prop stays) located above the haulage drift of the seam $l_{5}: 1$ - a change in the increment of roof displacements $\Delta u$ on the haulage drift contour; 2 -sliding average

\section{Discussion}

The experience of mines developing the steeply dipping coal seams shows that to ensure the operating state of zonal advance workings, it is preferable to use such protection methods as coal pillars (Fig. 1a) or special wooden structures (Fig. 1b, c). As a result of the experimental research, the conditions for the haulage drifts stability with different methods of protection have been substantiated (Fig. 1). For this, at specially equipped metering stations, the value of the side rocks displacement on the mine working contour has been determined (Fig. 2). It has been revealed that the most difficult conditions for supporting the haulage drifts are formed in the zone of stope works influence, when using protective structures with a stiff initial characteristic - coal pillars (Fig. 1a) or clumps of prop stays (Fig. 1c).

When protecting the haulage drift with coal pillars or clumps of prop stays (Fig. 1a, c), at a distance of $l=0-60 \mathrm{~m}$ behind the stope face, roof displacements reach values $u_{1-3}=320-400 \mathrm{~mm}$ and $u_{2-3}=220-370 \mathrm{~mm}$ (Fig. 3). At a distance of $l>60 \mathrm{~m}$, the side rock displacements on the haulage drift contour exceed the structural yielding property of the support, and the mine working section decreases by $50 \%$ (Fig. 3, 6).

When protecting the haulage drift with rolling-on chocks from sleepers, the side rocks convergence at the interval $l=0-60 \mathrm{~m}$ behind the stope face increases to the values $u_{1-3}=320-360 \mathrm{~mm}$ and $u_{2-3}=200-220 \mathrm{~mm}$ (Fig. 4). At a distance of $l=100 \mathrm{~m}$ along the haulage drift length, the displacements of benchmarks 1-3 and 2-3 reach maximum values and are equal to $u_{1-3}=350-380 \mathrm{~mm}$ and $u_{2-3}=220$ $290 \mathrm{~mm}$. Reduction in the drift section with this method of protection is about $30 \%$ (Fig. 6b).

Under normal mine conditions, protective structures located above the haulage drift are usually exposed to static loads. As the stope face advances, with an increases the mining site length and when protecting the haulage drift with coal pillars or clumps of prop stays, the calculated load on the protective structure also increases (Fig. 7, graphs 1.1; 1.2; 1.3; 3.2). Meanwhile, in conditions when the haulage drift is protected with rolling-on chocks from sleepers, the calculated load on the yielding protective structures gradually increases to a certain value, and then stabilizes (Fig. 7, graphs 2.2; 2.3).

To assess the conditions for supporting the haulage drifts with different methods of protection (Fig. 1), the change in the cross-sectional area of mine workings $S\left(\mathrm{~m}^{2}\right)$ along the 
mining site length is recorded (Figs. 2b, 6). It has been determined that the decrease in the cross-sectional area of the haulage drift when protecting with coal pillars or clumps of prop stays (Fig. 1a, c) changes almost linearly, with an increase in the distance $l(\mathrm{~m})$ from the stope face. It has been revealed that with such side rock displacements on the haulage drift contour (Fig. 3a, b, c), at a distance of $l \geq 60 \mathrm{~m}$ behind the stope face, the mine working section decreases to $50 \%$ (Fig. 6, graph 1.3).

In the case when the haulage drift is protected with rolling-on chocks made of wooden sleepers, a decrease in the mine working section up to $30 \%$ at a distance of $l=0-60 \mathrm{~m}$ behind the stope face is recorded. This can be explained by the intensification of the side rock displacements on the haulage drift contour during the initial compression of rolling-on chocks (Figs. 4, 6, graph 2). After the chocks compaction, mine working section decreases insignificantly (at $l \geq 60 \mathrm{~m}$, Fig. 6, dependence 2).

It is possible to substantiate the deterioration of the haulage drifts stability with different methods of protection (Fig. 1), using the dependences reflecting the change in the increment of roof displacements $\Delta u$ depending on the relative deformation $\varepsilon$ of protective structures (Figs. 9-11). To smooth out periodic deviations and identify characteristic deformation areas, a sliding average is applied (Formula (4)).

Analysis of the dependences shown in Figure 9 indicates that when protecting the haulage drift with coal pillars, after their deformation by $10-20 \%$ (zone AB, Fig. 9a, b, c), the protective structures stability is lost. At a distance of $l \geq 30 \mathrm{~m}$ behind the stope face, the roof displacements grow almost linearly (Fig. 3a, b, c), and the resistance of protecting pillars to external loads decreases (zones BC and DE in Fig. 9b, c). At a distance of $l \geq 80 \mathrm{~m}$, when the pillars deformation reaches $50-60 \%$, there is a final loss of the load-bearing capacity by the protective structures (zone DE, Fig. 9b, c). The drift stability deteriorates.

When protecting a haulage drift with rolling-on chocks made of wooden sleepers (Fig. 1b), when they are compressed and the protective structures are deformed by $50-60 \%$, the strongly marked yielding properties of the used protective structures, operating in the mode of constant resistance, are manifested. This has the most favourable effect on the operating state of the drifts. After that, at a distance of $l \geq 60 \mathrm{~m}$, rock displacements and a change in the haulage drift section practically cease (Fig. 4).

When protecting a haulage drift with clumps of prop stays, with their relative deformation in the range of $\varepsilon=0-0.2$, the used protective structures have strongly marked stiff characteristics. Upon reaching the relative deformation of the protective structures of $\varepsilon \approx 0.2$, the clumps of prop stays lose their load-bearing capacity and practically do not interfere with the side rocks convergence above the haulage drift (zone BC, Fig. 11). At a distance $l>15-25 \mathrm{~m}$ behind the stope face, the haulage drift section decreases, and the mine working support is deformed. The maximum reduction in the mine working section is $50 \%$ (Fig. 6).

Thus, based on the research performed, it can be concluded that when mining the steep coal seams in conditions of great depths, the protection of haulage drifts with initially stiff protective structures, exposed to brittle destruction (in this case, coal pillars or clumps of prop stays), is ineffective. It is possible to ensure the operating state of the zonal advance workings if, when unloading the coal-rock mass, the protective structures above the drift are stable and yielding. The protection of mine workings with rolling-on chocks made of wooden sleepers or by backfilling the mined-out space conforms these requirements. It is also obvious that it is possible to ensure the operating state of the haulage drifts by changing the deformation characteristics of the protective structures above the drift. This will restrict the side rocks displacement and preserve the integrity of the overhanging stratum in the coal-rock mass containing the mine workings.

\section{Conclusions}

When studying the peculiarities of the rock pressure manifestation in the haulage drifts of steep coal seams using the method of protecting with coal pillars or clumps of prop stays, an increase in the roof rock displacements on the mine working contour, as the stope face advances, has been determined. In this case, the rocks deformation at a distance of $l \geq 60 \mathrm{~m}$ behind the stope face exceeds the structural yielding property of the support, which leads to a decrease in the mine working section up to $50 \%$. The use of rolling-on chocks made of wooden sleepers to protect mine workings restricts the side rocks convergence on the haulage drift contour, as a result of which the mine working section at a distance of $l \geq 60 \mathrm{~m}$ is reduced to $30 \%$.

The deformation characteristics of the protective structures located above the haulage drift determine the system's ability to respond to the impact of various external factors, manifested in an anisotropic coal-rock mass during unloading. Protective structures, exposed to brittle destruction, and having an initial stiff characteristic (coal pillars or clumps of prop stays), with a relative deformation in the range of $0.1 \leq \varepsilon \leq 0.6$ lose their stability and load-bearing capacity. When the rolling-on chocks made of sleepers are deformed to values of relative deformation $\varepsilon=0.5-0.6$, as a result of their compression, accompanied by compaction of the material, without loss of load-bearing capacity, a smooth deflection of the roof and bottom above the haulage drift and restriction of rock displacements on the mine working contour are ensured.

A decrease in the haulage drift section when protecting with coal pillars or clumps of prop stays occurs after their destruction and loss of load-bearing capacity. When protecting mine workings with rolling-on chocks made of sleepers, a decrease in the mine working section occurs as a result of compression, without losing the load-bearing capacity of the protective structure above the drift.

\section{Acknowledgements}

The authors are grateful to A.V. Korol, postgraduate students Yu.I. Simonova and M.O. Grigorets for help when conducting experimental research.

\section{References}

[1] Tereshchuk, R.N., \& Naumovich, A.V. (2015). Obespechenie ustoychivosti podgotovitel'nykh vyrabotok glubokikh ugolnykh shakht. Dnepropetrovsk, Ukraina: NGU.

[2] Kang, H. (2014). Support technologies for deep and complex roadways in underground coal mines: A review. International Journal of Coal Science \& Technology, (1), 261-277. https://doi.org/10.1007/s40789014-0043-0

[3] Pravyla bezpeky u vuhilnykh shakhtakh. (2014). NPAOP 10.0-1.01-10. Retrieved from: https://zakon.rada.gov.ua/laws/show/z0398-10 
[4] Chepiha, D.A. (2019). Obgruntuvannia ta rozrobka sposobiv pidvyshchennia bezpeky pratsi hirnykiv u vyimkovykh dilnytsiakh hlybokykh shakht. PhD Thesis. Pokrovsk, Ukraina: Donetskyi Natsionalnyi Tekhnichnyi Universytet.

[5] Iordanov, I., Simonova, Y., Korol, A., Podkopayev, Y., \& Kayun, O. (2020). Substantiation of conditions of maintaining stability of haulage drifts during development of steep seams. Technology Audit and Production Reserves, 3(1(53), 23-26. https://doi.org/10.15587/27065448.2020.206009

[6] Mohamed, K.M., Murphy, M.M., Lawson, H.E., \& Klemetti, T. (2016). Analysis of the current rib support practices and techniques in U.S. coal mines. International Journal of Mining Science and Technology, 26(1), 77-87. https://doi.org/10.1016/j.ijmst.2015.11.014

[7] Podkopaev, S.V., \& Chepiga, D. (2018). On the prediction of the stability of haulage gates under different methods of protection in deep mines. Journal of Donytsk Mining Institute, 2(43), 18-29. https://doi.org/10.31474/1999-981x-2018-2-18-29

[8] Galvin, J.M. (2016). Ground engineering - principles and practices for underground coal mining. London, United Kingdom: Springer. https://doi.org/10.1007/978-3-319-25005-2

[9] Shashenko, A.N., Pustovoytenko, V.P., \& Sdvizhikova, E.A. (2016). Geomekhanika. Kiev, Ukraina: Novyi druk.

[10] Podkopaiev, S., Gogo, V., Yefremov, I., Kipko, O., Iordanov, I., \& Simonova, Y. (2019). Phenomena of stability of the coal seam roof with a yielding support. Mining of Mineral Deposits, 13(4), 28-41. https://doi.org/10.33271/mining 13.04.028

[11] Wang, H., Wu, Y., Liu, M., Jiao, J., \& Luo, S. (2020). Roof-breaking mechanism and stress-evolution characteristics in partial backfill mining of steeply inclined seams. Geomatics, Natural Hazards and Risk, (11), 2006-2035. https://doi.org/10.1080/19475705.2020.1823491
[12] Hong-sheng, T., Shihao, T., Cun, Z., Lei, Z., \& Xiaogang, Z. (2017). Characteristics of the roof behaviors and mine pressure manifestations during the mining of steep coal seam. Archives of Mining Sciences, (62), 871-891. https://doi.org/10.1515/AMSC-2017-0060

[13] Zhang, N., Yuan, L., Han, C., Xue, J., \& Kan, J. (2012). Stability and deformation of surrounding rock in pillarless gob-side entry retaining. Safety Science, (50), 593-599. https://doi.org/10.1016/J.SSCI.2011.09.010

[14] Krupnik, L., Shaposhnik, Y., Shaposhnik, S., \& Tursunbaeva, A.K. (2013). Backfilling technology in Kazakhstan mines. Journal of Mining Science, (49), 82-89. https://doi.org/10.1134/S1062739149010103

[15] Chen, S., \& Zhang, Z. (2019). Determination of coal pillar width and support parameters in deep coal mines - A case study. Journal of Testing and Evaluation, 47(4), 3160-3173. https://doi.org/10.1520/JTE20170054

[16] Kleppner, D., \& Kolenkow, R. (2010). An introduction to mechanics. Cambridge, United States: Cambridge University Press. https://doi.org/10.1017/CBO9780511794780

[17] Pariseau, W. (2006). Design analysis in rock mechanics. London, United Kingdom: CRC Press. https://doi.org/10.1201/9780203968253

[18] Molugaram, K., \& Rao, G.S. (2017). Statistical techniques for transportation engineering. Oxford, United States: Butterworth-Heinemann.

[19] Chatfield, C. (2016). The analysis of time series: An introduction. London, United Kingdom: CRC Press.

[20] Phang, M.K., Simpson, T.A., \& Mesbahi, M. (1982). Timber cribbing design for coal mine roof control. London, United Kingdom: CRC Press.

[21] Skrzypkowski, K. (2020). Comparative analysis of the mining cribs models filled with gangue. Energies, (13), 5290. https://doi.org/10.3390/en13205290

[22] Barczak, T.M., \& Gearhart, D.F. (1994). Optimising wood crib design, improving ground control and reducing wood costs. Engineering and Mining Journal, 195(12), 23-30.

\section{Експериментальні дослідження стійкості відкаточних штреків на пластах крутого падіння}

\section{I. Іорданов, І. Булега, Я. Бачуріна, Г. Бойченко, В. Довгаль, О. Каюн, О. Когтєва, С. Подкопаєв}

Мета. Обгрунтування умов стійкості відкаточних штреків при різних способах охорони на пластах крутого падіння на основі комплексу експериментальних досліджень.

Методика. Для досягнення поставленої цілі були виконані шахтні інструментальні спостереження з вивчення проявів гірського тиску в дільничних підготовчих виробках, що примикають до очисного забою на відкаточному горизонті. Умови їх підтримки в межах виїмкової дільниці оцінювались величиною конвергенції бічних порід на контурі штреку та зміною площі перерізу з урахуванням деформаційних властивостей охоронних споруд.

Результати. Зафіксовано, що в зоні впливу очисних робіт, в найбільш складних умовах підтримуються відкаточні штреки, коли для їх охорони використовують цілики вугілля або кущі зі стойок. Встановлено, що зменшення перерізу виробок до 50\% в таких умовах, відбувається в результаті руйнування охоронних споруд. При охороні відкаточних штреків накатними кострами, зменшення перерізу до $30 \%$ відбувається в результаті їх стиснення. Встановлено, що при деформуванні ціликів вугілля або кущів зі стойок до 10-20\% відбувається втрата їх стійкості, а зростання до 50-60\% призводить до повної втрати їх несучої здатності, інтенсифікації зміщень порід на контурі виробки й погіршенню ії стійкості. Визначено, що в результаті деформування накатних кострів зі шпал на 20-60\% відбувається їх стиснення без втрати несучої здатності, що забезпечує плавний прогин нависаючої товщі та обмеження зсувів порід на контурі відкаточного штреку.

Наукова новизна. Для вивчення деформаційних характеристик надштрекових охоронних виробок використана функція приросту зсувів бічних порід на контурі відкаточного штреку по довжині виїмкової дільниці від відносних деформацій охоронних споруд, що дозволить оцінити реальну динаміку процесу.

Практична значимість. При відпрацюванні крутих вугільних пластів, використовуючи особливості геомеханічних процесів, що проявляються в анізотропному вуглепородному масиві при розвантаженні, задовільну стійкість виробок можна забезпечити за рахунок зміни деформаційних властивостей надштрекових охоронних споруд.

Ключові слова: гірський тиск, итрек, підтримка гірських виробок, ияілик, костри, охоронні споруди, породи, вуглепородний масив

\section{Экспериментальные исследования устойчивости откаточных штреков на пластах крутого падения}

\section{И. Иорданов, И. Булега, Я. Бачурина, Г. Бойченко, В. Довгаль, А. Каюн, О. Когтева, Е. Подкопаев}

Цель. Обоснование условий устойчивости откаточных штреков при разных способах охраны на пластах крутого падения на основе комплекса экспериментальных исследований.

Методика. Для достижения поставленной цели были выполнены шахтные инструментальные наблюдения по изучению проявлений горного давления в участковых подготовительных выработках, примыкающих к очистному забою на откаточном горизонте. Условия их поддержания, в пределах выемочного участка, оценивались величиной конвергенции боковых пород на контуре штрека и изменением площади поперечного сечения, с учетом деформационных свойств охранных сооружений.

Результаты. Зафиксировано, что в зоне влияния очистных работ, в наиболее сложных условиях поддерживаются откаточные штреки, когда для их охраны используют целики угля или кусты из стоек. Установлено, что уменьшение сечения таких выработок до $50 \%$, является результатом разрушения охранных сооружений. При охране откаточных штреков накатными кострами, уменьшение сечения выработки до $30 \%$ происходит в процессе сжатия охранных сооружений. Установлено, что при деформировании цели- 
ков угля или кустов из стоек до 10-20\% происходит потеря их устойчивости, а рост до $60 \%$ приводит к полной потере их несущей способности, интенсификации смещений пород на контуре выработки и ухудшению ее устойчивости. Определено, что в процессе деформирования накатных костров из шпал на 20-60\%, происходит их сжатие без потери несущей способности, что обеспечивает плавный прогиб нависающей толщи и ограничение смещений пород на контуре откаточного штрека.

Научная новизна. Для изучения деформационных характеристик надштрековых охранных сооружений использована функция прироста смещений боковых пород на контуре откаточного штрека по длине выемочного участка от относительных деформаций охранных сооружений, что позволило оценить реальную динамику процесса.

Практическая значимость. При отработке крутых угольных пластов, используя особенности геомеханических процессов, которые проявляются в анизотропном углепородном массиве при разгрузке, удовлетворительную устойчивость выработок можно обеспечить за счет изменения деформационных свойств надштрековых охранных сооружений.

Ключевые слова: горное давление, итрек, поддержание горных выработок, целик, костры, охранные сооружения, породы, углепородный массив 